\title{
The Teaching of Enzymes: A Low Cost Experimental Approach with High School Students.
}

\author{
PINHEIRO, W. A ${ }^{1}$; FERNANDES, K. V. $\mathrm{S}^{2}$; DANSA-PETRETSKI, $\mathrm{M}^{2}$ and \\ POMPILHO, W. M ${ }^{1}$ \\ CEDERJ - Pólo Itaperuna, UENF, Rio de Janeiro; Brazil ${ }^{1}$ \\ LQFPP, CBB, UENF, Rio de Janeiro; Brazil
}

The association of experimental methods with the traditional lecturing of Science themes is encouraged by several authors. The importance of conducting experimental classes is undeniable, as practical activities motivate students to search for knowledge. But this is not the reality in most public schools in the inlands of Rio de Janeiro's State, where several factors prevent teachers from using such didactic strategy. The aim of this work was demonstrate low-cost experimental activities, addressing the subject enzymes. The practice has been designed for being held in a common classroom. Lab glassware was replaced by alternative materials. Potato extract (catalase source) and commercial hydrogen peroxide were required. Concepts such as kinetic data related to substrate concentration, time of reaction, $\mathrm{pH}$ and temperature effects on enzymatic activity have been explored with the students. Graphical representation of enzyme activity related to the above parameters has also been elaborated. The practice was held in 10 schools distributed among 7 different cities. Questionnaires have been applied to the students before and after the practice and revealed that $86 \%$ of the students had never participated of a practical lesson and $49 \%$ were unaware of the function of enzymes. After practice, $68 \%$ of the students said that the enzymes catalyze biological reactions and $73 \%$ considered the practice important to their cognitive achievement. The evaluation of information obtained from students confirmed the lack of practical activities in public education, as well as the capacity that the practical activities have to motivate the students in the knowledge formation process.

Keywords: Teaching of Biochemistry; Catalase; Classroom Practice. 